\title{
ANALYSIS OF THE CAPITAL STRUCTURE FORMATION: THE CASE OF GEORGIAN IT COMPANIES
}

\section{GRIGORIY GURBANOV}

\author{
PhD Student
}

Sokhumi State University, Georgia

grtm911@gmail.com

\begin{abstract}
Any country's economy benefits significantly from the sector of information technologies. As the data demonstrate, the global information technology market has not only remained stable, but is expected to expand in 2021 due to changes in social life, employment, and education caused by the global COVID-19 virus pandemic. While information technology is vital to any country's advancement, its growth in developing countries is being hindered by lack of skilled labour force, underdeveloped market infrastructure, insufficient financial mechanisms to stimulate innovative projects, and weak legislative framework. IT companies are characterized by a high degree of risk and uncertainty, a reliance on external sources of financing in the early stages, and an unattractiveness to conservative investors. In this regard, the issue of capital formation for innovative companies in the IT sector to ensure their effective functioning becomes especially important. The purpose of this study is to analyze the formation of financial sources and capital structure of Georgian IT companies based on the analysis of 50 IT companies in Georgia. The analysis is based on the usage of the main financial ratios of companies' performance, taking into account the specifics of the IT sector companies. The study revealed that the capital structure of Georgian information technology firms is more consistent with the Pecking order theory, with almost no long-term loans and a small share of short-term loans. Equity and retained earnings are the primary sources of funding for IT businesses. This was supported by the legal exemption of corporations from income tax payments in the case of net profit non-distribution.
\end{abstract}

KEYWORDS: INFORMATION AND COMMUNICATION TECHNOLOGIES (ICT), INFORMATION TECHNOLOGY (IT) MARKET, INNOVATION, FINANCIAL INDICATORS.

For citation: Gurbanov, G. (2021). Analysis of the capital structure formation: the case of Georgian IT companies. Globalization and Business, №11, 152-156. https://doi.org/10.35945/gb.2021.11.023

Actuality. Implementation of innovative projects requires significant financial resources.

While firms in non-ICT sectors can afford to choose whether or not to finance innovation, ICT firms do not have this choice. According to some research, the financial position of IT firms that financed the invention but had to abandon the project due to a lack of appropriate funding is better than that of firms that did not innovate at all (Planesa, ... et al, 2001), is due to ICT industry peculiarity, in which companies that do not innovate exit the market.

The modern ICT market is influenced by a combination of two processes: globalization and specialization. One example of globalization is the widespread use of specific software developed by various large and small companies by many millions of users around the world. Specialization refers to the development and implementation of certain technologies to solve specific problems. Even though that large ICT companies have significant resources for the implementation of innovative projects, advantages of small ICT-companies in innovation are mobility and flexibility in decision making, strong motivation, and narrow specialization, focus on a result, ability to take a conscious risk. The problem of small ICT enterprises is their inability to perform large IT projects on their own, weak scientific and production base, lack of sufficient financial, material and information resources to perform independent ICT projects.

IT sector has a special place in the high-tech market. According to research company Gartner, despite the negative effects of the pandemic on the global IT industry in 2020, the high demand for information technology, due to shifts in social norms of work and education, softened the impact of the crisis, and the market volume in 2021 would be $\$ 3.9$ trillion, 6.2 percent higher than the previous year (Gartner, 2021). The structure of global spending on IT technologies is presented in Table 1. The table shows that the largest share falls on communication costs and IT services.

The sector has gone through several stages in its development. The first stage included the development of large universal high-performance servers with significant input and output resources (mainframes), the core developer of which was IBM Company in 1964 . The second stage included the creation of a platform base on personal computers, client/ server architecture, Internet. Social networks and cloud infrastructure was developed in the third stage. New social tech- 
nologies, "big data" and new data sources drive forward the digital revolution and has made a significant contribution to the processes of globalization. In general, IT companies operate in all segments of the market.

Formulation of a problem. Capital structure management ensures the company's financial stability and influences all of the basic characteristics of capital as an object of management. Due to the effect of financial leverage the ratio of these funds affects performance targets of a company (for example, the company's market value, risk and profitability), its creditworthiness and financial stability.

There are many studies the have focused on the optimal capital structure, however, as practice has shown, there is no universal approach to the issue and selection of criteria for optimal debt burden depends on the industry, organizational and legal form of entity, adopted financial policy, the stage of the company's life cycle and other factors. Managerial decision-making process examines the consequences of choosing particular financing sources for owners, including assessment of impact of future returns and risks. It is logical to assume that the optimality of capital structure is related to opportunities to obtain maximum value at the lowest possible cost.

The primary goal of this study is to analyze the formation of funding sources and the capital structure of Georgian IT companies using an analysis of 50 Georgian IT companies (for the period 2018-2019) in order to identify the existing capital structure in Georgia's ICT sector. The findings of the study would provide managers of ICT companies and all stakeholders with data to help them make sound financial management decisions. The analysis is based on the use of the main financial ratios of companies' performance, taking into account the specifics of the IT sector companies. The data and financial statements for the research was obtained from public information resource reportal.ge.

Theoretical background of the study. Different considerations are defined in the economic literature that managers use when selecting a source of funding. The cost of capital, which involves the calculation of both the debt and equity costs, is first and foremost among these. The total cost of capital is calculated on the basis of the weighted average cost of capital (WACC), taking the weight of each source of capital

Table 1. Structure of global spending on IT technologies (\%)*

\begin{tabular}{|l|c|c|}
\hline \multirow{2}{*}{\multicolumn{1}{|c|}{ Spending }} & $\mathbf{2}$ Year \\
\cline { 2 - 3 } & $\mathbf{2 0 2 0}$ & $\mathbf{2 0 2 1}$ \\
\hline $\begin{array}{l}\text { Data Center } \\
\text { Systems }\end{array}$ & 5,82 & 5,82 \\
\hline $\begin{array}{l}\text { Enterprise } \\
\text { Software }\end{array}$ & 12,59 & 12,89 \\
\hline Devices & 17,68 & 17,98 \\
\hline IT Services & 27,38 & 27,34 \\
\hline $\begin{array}{l}\text { Communications } \\
\text { Services }\end{array}$ & 36,53 & 35,96 \\
\hline Overall IT & $\mathbf{1 0 0}$ & $\mathbf{1 0 0}$ \\
\hline
\end{tabular}

*Source: Gartner, Authors calculations into account and when the capital structure (ratio of equity to debt) changes, the WACC will change.

Another significant factor which enables managers to assess the risk of decision-making is the degree of total leverage. This metric consists of two components which cause changes in the level of EBIT and EPS of a company. These components are the level of operating and financial leverage of a company. Operating leverage measures the sensitivity of operating income to changes in sales, while financial leverage, arising from a financial sourcing decision impacts the EPS by incurring fixed financial costs in the form of interest on loans or dividends on preferred shares. Financial leverage enhances the operating leverage, and both together enable managers to assess the potential cumulative risk of a business.

The level of financial leverage affects the degree to which the owners control the company, its managerial flexibility. Issuance of shares and an increase in the number of shareholders cause dilution of the share of existing shareholders. In addition, lenders can impose restrictions on certain transactions. The higher the degree of debt, the lower the company's credit rating, and the lower the ability to choose its capital sources at the desired price. As a consequence of this situation, the weighted average cost of capital will increase, as the company will be forced to use costly sources of funding, resulting in a decline in liquidity, economic value added and market value of the company.

The level and variability of operating profit (EBIT) is also closely correlated with managerial flexibility. The high value of this indicator allows projects to be funded independently or sources of funding to be more freely selected, whereas operating profit is critical for meeting financial costs. In the case of joint stock companies, the EPS (earning per share) metric is used in addition to EBIT when choosing a source of funding. The issuing of additional shares to attract funding may result in a reduction of the EPS and, if the manager's performance is measured on the basis of this metric, such decisions would be avoided by managers.

The structure of assets is seen by certain analysts as an independent variable affecting the decision on the source of funding. Although it is closely linked to the degree of operating leverage, it has an indirect influence on the level of financial leverage and managers necessarily consider it during financial leverage analysis. The higher the level of fixed assets, the higher the level of operational leverage and the more managers are constrained in their decision to borrow.

Sales growth rate has a dual effect on funding decisions. In the absence of sales growth, the effect of operating leverage is neutralized, which frees managers in borrowing decisions. On the other hand, sales growth requires additional financing, but at the same time, in companies with high fixed financial costs, the level of total leverage and risk also grows.

Another important factor is the lifecycle of a company. Start-up companies find it much more difficult and costly to raise borrowed funds than big, mature companies, as investors are seeking a risk premium.

The financial market conditions also affect the management decision-making process. The unfavorable condition in the stock market can force managers to make decisions in 
favor of debt financing, and the issue of bonds is profitable when interest coupon rates decline, the same is true in the case of bank borrowing.

Thus, the analysis of the above factors is the basis for the formation of an optimal capital structure, which will be linked to the strategic and financial goals of the company.

Many theoretical works are devoted to models of the optimal capital structure. The foundations of the theory was laid by J. Williams. In 1938 he substantiated the concept of discounted cash flow and, on its basis, proposed a stock valuation model based on dividend discounting. Anticipating Modigliani's work, he argued that profit, not dividend policy, affects the growth of a firm's value, whether or not it pays dividends. D. Durand (1938) made the greatest contribution to the advancement of the traditional theory of capital structure, according to which decisions on capital structure have an effect on weighted average cost of capital (WACC) and the value of a company. The level of debt, after which there is an increase in the cost of equity capital, is the optimal capital structure that provides the maximum value of the firm.

In contrast to traditional theory, in 1958 Modigliani and Miller proposed the theory that there is no optimal capital structure in the ideal capital market without taxation. In 1963, the theory was revised by introducing the taxation factor into the model. According to a new theory, if a company pays the profit tax, the market price of a company that uses financial leverage is higher than the market price of a company that does not use it for the amount of profit tax savings and the optimal capital structure is $100 \%$ debt capital.

Trade-off theory assumes that optimal capital structure depends on a balance between tax benefits from debt taking and bankruptcy costs. The theory does not provide a specific value for the optimal capital structure, but asserts that the balance can be achieved by comparing discounted tax shields and expected bankruptcy costs.

The theory's subsequent development resulted in the development of signaling models, which establish a capital structure based on constant market information analysis that does not necessarily maximize the company's value. The models developed within the framework of this theory account for information asymmetry, which occurs when compa- ny managers know more about the company than the market. As a result, managers can send signals to outside investors by making financial decisions like capital structure selection.

The Pecking order theory, developed by S. Myers and N. Majluf in 1984, was the most widely used model within the framework of this theory. This theory was able to answer a question that previous theories had been unable to answer: why do companies with high profitability choose low levels of financial leverage? Firms, according to Myers, prefer to use internal sources of funding in the form of retained earnings when deciding on a source of funding. When this resource is depleted, they will move on to the next type of financing, debt capital and convertible bonds, which are the last resort for issuing common stock. Thus, we can assume that this model ignores the risks and advantages of forming a new debt unit.

Analysis of the ICT sector of Georgia. The digitalization processes had a major influence on corporate practices, education, and other facets of social life. As a result, any nation, including Georgia, has made ICT development one of its top priorities. Georgia leads the Caucasian countries on ICT goods exports with 0,4 \% in 2019 (see Chart 1), which include computers and peripheral equipment, communication equipment, consumer electronic equipment, electronic components, and other information and technology goods. This indicator is 11 times less than the average indicator for Europe and Central Asia (classification of countries according to the World Bank). The average of ICT export for these countries is $4.5 \%$.

For the period 2013-2019, the GDP level generated in the information and communications sector has been steadily growing. In current prices, the indicator increased from 854.2 million GEL to $1323.8 \mathrm{GEL}$, representing 2.7 percent of total GDP (see Chart 2). The sector employs on average 1.6 percent of the total working population (from 2017 to 2019), or approximately 20,000 people.

We performed a financial analysis of 50 Georgian information and communication technology firms in order to accomplish the goals of research. According to the requirements outlined in the Low on Accounting, Reporting, and Audit, 38 of the evaluated companies fall into the third group,

Chart 1. ICT goods exports in Georgia, Armenia, Azerbaijan, Europe and Central Asia (\% of total goods exports) *

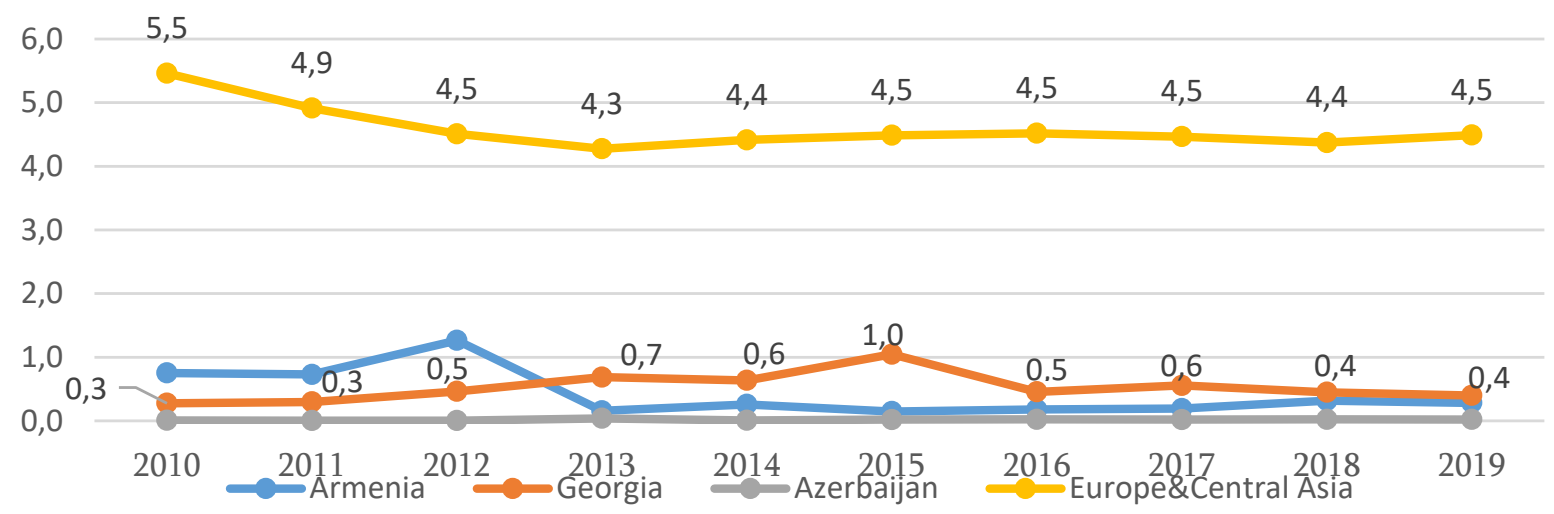

*Source: World Bank data. URL: https://data.worldbank.org 
Chart 2. The dynamics of the GDP level produced by the ICT sector from 2010 to 2019*

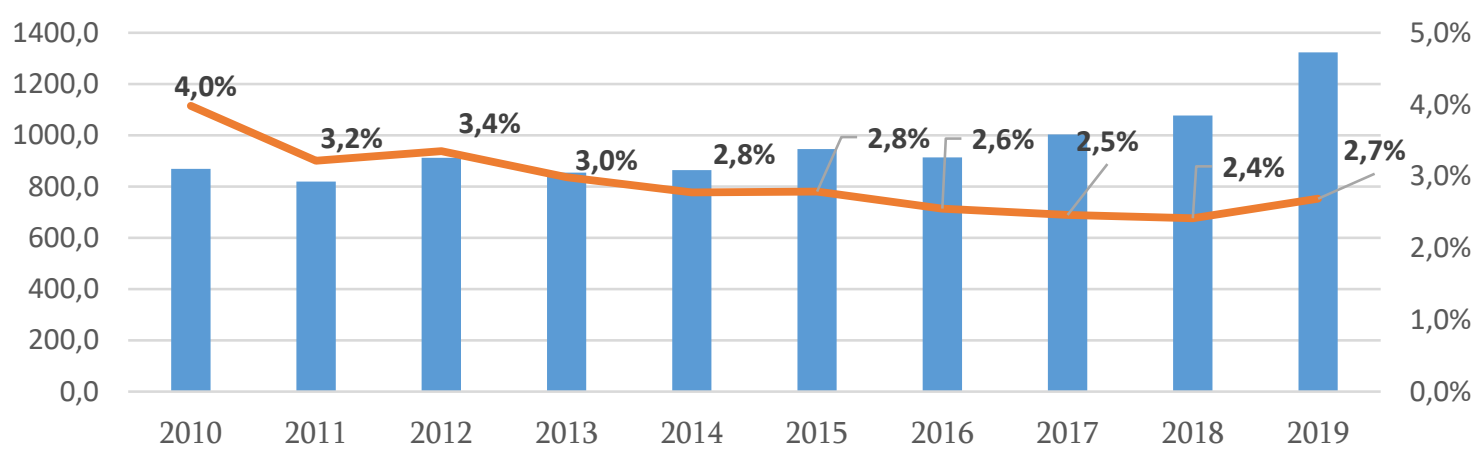

GDP created by ICT sector ( $\mathrm{mln}$. Gel) $\quad$ GDP created by ICT sector, \% to total GDP

*Source: Geostat.ge; authors calculation

nine into the second, and three into the first (selection criteria are presented in the table 1 ).

The analysis showed that, in contrast to the Western ICT market, sales of foreign-made equipment prevail in the market structure (70\% of analyzed companies), and only $30 \%$ falls on the ICT services sector. Hardware sales, which account for more than $55 \%$ of the ICT market, reduce the opportunities for the formation of the IT services market and its attractiveness for investment.

As for the financial ratios of the analyzed companies, attention is drawn to the very low use of debt financial ratios in the period $2018-2019.70 \%$ of the analyzed companies fall into the second and third classifications, with no long-term liabilities in their liabilities structure and relying on short-term liabilities to fund their operations. Just three out of thirteen newly founded companies registered in the last five years have been able to obtain long-term loans. Simultaneously, one of these companies, S-G-L Ltd, was established through foreign investment, and the other, Maxnet Ltd, was formed through the merger of three previously operating companies on the market (TV NET Ltd; Thernet Ltd; Sanet Ltd). 48 of the 50 companies have a degree of financial leverage close to one, confirming that companies do not have the ability to use the impact of financial leverage to boost earnings and business value.

The short-term liabilities structure review found that more than $60 \%$ of companies that were surveyed did not use short-term credit. Twelve of the eighteen companies (67\%) that use this form of funding have a debt level of less than $40 \%$. Thus, $50 \%$ of all analyzed companies depend heavily on accounts payable, which accounted for 83 percent of total liabilities. $46 \%$ of businesses have no authorized capital and $100 \%$ fund their operations from retained earnings. It should be remembered that approximately $80 \%$ of businesses do not pay income tax and take advantage of tax exemptions associated with non-distribution of profits.

With regard to the influence of the business sector in attracting long-term loans, companies whose structure exceeds $50 \%$ of the long-term debt are mostly owned by large telecom and internet companies (Global Erty JSC, Caucasus Online Ltd, Magticom Ltd, Silknet JSC, Vion Georgia Ltd, Railway Telecom Ltd). The stated trend is supported by the Debt-to-Equity Ratio and 90 percent of businesses, which averaged 0.11 percent in 2018 and 0.14 percent in 2019 for 90\% of companies (the only exception is Railway Telecom, where long-term debt was 35 times greater than equity capital, bucking the trend).

The analysis of the coverage ratio showed that, $46 \%$ of businesses did not pay financial interest, since they were debt-free. In 2018, 16\% of businesses were unable to meet financial expenses by operating profit, and this figure rose to $22 \%$ in 2019.

The most frequently used and readily available metric for describing the operations of IT firms is gross revenue. For the period 2018-2019, $54 \%$ of the analyzed companies demonstrated an improvement in this measure. The liquidity levels of $16 \%$ of companies are less than one (normal range $\geq$ 1), $44 \%$ of companies have a value greater than four, and the remaining companies have a value between 1-2.

Table 1. Classification of Georgian ICT Companies by different criteria

\begin{tabular}{|c|c|c|}
\hline Group & Criteria & $\begin{array}{c}\text { Quantity, } \\
\%\end{array}$ \\
\hline I & Total Assets Value > GEL 50 mln., Revenue > GEL 100 mln. 3Lari, Avg. Number of Employees > 250 & 1 \\
\hline II & Total Assets Value < GEL 50 mln., Revenue < GEL $100 \mathrm{mln}$. Lari, Avg. Number of Employees < 250 & 5 \\
\hline III & Total Assets Value < GEL 10 mln., Revenue < GEL 20 mln. Lari, Avg. Number of Employees < 50 & 35 \\
\hline IV & Total Assets Value < GEL 1 mln., Revenue < GEL 2 mln. Lari, Avg. Number of Employees < 10 & 59 \\
\hline
\end{tabular}




\section{CONCLUSION}

Optimizing the capital structure is one of the most critical activities of a financial manager. Capital structure theories provide a foundation for choosing the strategic directions of development of every company. Optimal structure policy involves finding a trade-off between risk (acceptable level of financial stability ratio) and return (level of financial profitability). The estimation also includes the weighted average cost of capital and maximization of the market value of a firm.
The study showed that Georgian IT companies finance their assets using a combination of retained capital and accounts payable. Companies tend to finance operations from their own resources, which is more consistent with the Pecking Order Theory. The low level of leverage indicators suggests that the industry has considerable growth capacity, which companies are underutilized for objective reasons. In order to maximize the benefit and value of IT firms, company executives must reconsider capital formation strategies and diversify funding sources.

\section{REFERENCES:}

Bedianashvili, G. (2017) Formation of Knowledge Economy and Innovative Entrepreneurial Policy: Institutional Aspects. Globalization and Business, 3:10-16.

Grant, D., Yeo, B., (2018). A global perspective on tech investment, financing, and ICT on manufacturing and service industry performance. International Journal of Information Management Volume 43, December, Pages 130-145 https://doi. org/10.1016/j.ijinfomgt.2018.06.007

Gartner (2021). Gartner Forecasts Worldwide IT Spending to Grow 6.2\% in 2021. https://www.gartner.com/en/newsroom/ press-releases/2020-01-25-gartner-forecasts-worldwide-it-spending-to-grow-6-point-2-percent-in-2021

Kedzior, M., Grabinska, B., Grabinski, K., Kedzior D., (2020). Capital structure choices in Technology Firms: empirical results from Polish listed companies. Journal of Risk and Financial Management. Journal of Risk and Financial Management, vol. 13 , issue 9:1-20

Leon F. (Long-term finance and entrepreneurship. https://www.researchgate.net/publication/333436891_Long-term_finance_and_entrepreneurship

Nanda, R. and Rhodes-Kropf, M., (2017). Innovation policies, entrepreneurship, innovation, and platforms, Emerald Publishing Limited:37-80.

Maglakelidze, A., (2020). Technological Innovations and Opportunities for Entrepreneurship Development In Georgia. Globalization and Business, 10: 264-269. https://doi.org/10.35945/gb.2020.10.036

Planesa, B., Bardosa, M., Sevestreb, P. and Avouyi-Dovib, S., (2001). Innovation: Financing and Financing Constraints. September. https://www.bis.org/publ/cgfs19bdf3.pdf 